\title{
Realistic and Unrealistic Direst Costs in Pharmacoeconomic Anesthesia Studies
}

\author{
Branislava M. Majstorović ${ }^{1}$, Branko D. Milaković ${ }^{1,2}$ \\ ${ }^{1}$ Institute for anesthesiology and resuscitation, Clinical Center of Serbia, Belgrade, Serbia \\ ${ }^{2}$ Medical school, University of Belgrade, Belgrade, Serbia
}

\section{SUMMARY}

Introduction: Multiplicity of anesthetic services and practice consume few resources individually, but collectively, they mean significant cost. Economic and pharmacoeconomic studies are done in order to rationalize resources.

Aim: 1 . To calculate the direct expense in anesthesia and reanimation; 2 . To compare expenses to the price of anesthesia according to the unit prices of National Health Insurance Fund (NHIF); 3. To compare the duration of general anesthesia with costs in anesthesia departments.

Methodology: This paper is a part of the retrospectively-prospective academic study of fourth phase carried out in the Clinical Center of Serbia. With permission of Ethical committee, we have set for 2005 and 2006, the direct cost of 148.876 anesthetic services in 11 departments of Clinical Center of Serbia as tertiary-type institution of medical health care. Research group included all patients of both sexes, children and adults. We compared the direct cost per minute of general anesthesia with average duration of anesthesia in every anesthesia department of surgical clinics. The direct cost was compared with the same, 'unit' prices of NHIF. The direct cost was compared with the same, 'unit' prices of RHIF. We have used linear and regression statistical product and service solutions model for component cost analysis /SPSS 15/.

Results: Most budget resources are selected for the employees' sallaries (40\%), then the medicines and supplies $(31,80 \%)$ and the other expenses including the analysis and analytic devices $(28,20 \%)$. Direct costs indicate a linear correlation and statistically marked difference $p=0,012, F=9,270$ compared to anesthesia duration indicating the coefficient of correlation $r=0,694$. Direct costs are highest considering longest segment of anesthesia. We have obtained linear correlation $\mathrm{R}=0,706$ for direct costs excluding the neurosurgical anesthesia with 'unit prices' of anesthesia and anesthetic services indicating $F=9,951$ and $p=0,01$.

Conclusions: Anesthesia and anesthetic services show statistically significant and financially significant correlation with the direct costs and duration of anesthesia within different surgical specialties. Cosidering direct costs, only the costs of anesthetic drugs and materials are realistic, and all other elements are determined by law and by contract with NHIF. Other costs, out of the direct costs group shall be theoretically reduced by running the analyzes required for anesthesia and for the planned surgical intervention in primary health care protection. Data base related to surgical data and better computer programs able to monitor multiple parameters during hospital treatment, could determine more precisely the value of anesthetic services.

Keywords: general anesthesia, costs, direct, indirect, total 


\section{INTRODUCTION}

In modern time, the progress of medical knowledge and technology brings new and more efficient methods of the treatments in relation to the standard, but more expensive treatments. Health care costs are thus increasing more rapidly than the gross national product of many countries. Economic and pharmacoeconomic assessments are made for the purpose of rationalization of medical resources.

Anesthesiology and resuscitation are the results of primordial human need to alleviate or cause loss of pain, both during the illness and during surgical interventions. As a separate unit within the surgical discipline, anesthesiology, and resuscitation, developed the specific principles for each surgical discipline in addition to general principles. Anesthesia, intensive care units (ICU) and the treatment of pain are the courses of developed anesthesiology and resuscitation. The safety of patients and the risks of anesthesia, pose just alike high levels of risk to surgical disciplines [1,2]. Biochemical and chemical analysis, electrocardiogram and lung $\mathrm{x}$-ray are necessary for anesthesia, due to the assessment of the optimal state of patients' health and the risk of running the anesthesia. Anesthesiology involves diagnosis and treatment of most diseases, primarily surgical, but also cosmetic surgery in healthy people. However, in particular, it doesn't cure any diseases. In economic studies, anesthesiology and Resuscitation are displayed as part of the clinical support in surgery. Anesthesiology is a service organized by the departments of anesthesiology and resuscitation in its master clinics. In secondary and tertiary health care protection during hospital treatment it is the responsibility of anesthesiologists.

In Serbia, the economic structure of anesthetic work is based on data for collection charges of anesthetic services for National Health Insurance Fund (NHIF) which raises and distributes funds to the hospital management. Anesthetic services are fiscally warranted by three groups. The first group includes different types of general anesthesia, the second includes various techniques of local anesthesia and the third group includes following anesthetic procedures: anesthesia, analgesia, sedation, analgosedation, controlled hypotension in the ICU, canulation of the central arterial and venous blood vessels, etc. Price list of medical services, and anesthesia was regulated by the Council of the NHIF in the Belgrade in 1990 and it is regularly adjusted [3]. Modern regulations, in accordance with European are the nomenclature of health services at the secondary and tertiary level of health care protection in addition to the Regulations on the prices of health care services at the secondary and tertiary levels implemented in 2014 [4,5].

In foreign literature, anesthetic work is measured by the number and duration of anesthesia and is defined as the sum of the basic anesthesia unit and the unit of time divided by the total hours of anesthetic work $[6,7,8]$. Longer anesthesia, compared to the shorter anesthesia is considered as factor negatively influencing the cost of treatment, as thus increasing the cost of anesthesia. Therefore, we compared the duration of anesthesia with direct costs. Price does not always correlate with the actual expanses [9]. The aim is financing of the expanse based on real consumption of resources such as medical staff, knowledge, time, facilities and equipment for each service.

Medicines, medical supplies and appliances are real, visible costs required to be purchased from the pharmaceutical and concomitant industries. These costs are easy to be controlled and checked by those who allocate funds for this purpose and/or use them in their work.

Direct medical costs are costs of the medical procedure. Direct medical costs can be divided into direct expenses of treatments such as doctors' and nurses' payrolls - personal expenses; medicines, non-medicinal supplies, medical, laboratory analyzes and the necessary anesthetic apparatus; hospital day in the ICU as the responsibility of the anesthesiologist, and direct costs of non-health services. Direct non-medical costs include the costs of transport of patients to the hospital and back, but rarely are calculated because the anesthesiologist's work begins with a secondary level of public health.

Indirect costs relate to loss of patients salaries due to illness, disability or death, if the cost analysis is viewed from the aspect of general population.

Average costs are obtained by dividing the total direct costs of anesthetic services with the total number of applied anesthetic services.

Non-material costs relate to psychological aspects of disease or the therapy, e.g. Discomfort, pain and suffering although, non 
- material costs are rarely counted in practice due to obstacles in real numeration of cognitive characteristics.

Marginal costs include costs of additional emergency units. Discounting is an economic term meaning the time advantage and represents in this study a clear actual value of anesthesia. Spending resources and benefits in treatments do not happen at the moment and there is time gap between costs and effects. The discount rate is the contractual category, distinguished by states and greatly influenced by inflation means.

Researches [10,11,12] indicate that the direct costs are mostly influenced by the fallowing facts: general condition of the patients, degree of urgency, types and levels of anesthesia procedures, personnel expense, consummation of anesthetics and other medications required for the use of anesthesia and/ or resuscitation, their cost of medical and non-medical materials etc. The time required to perform anesthetic services consumption of drugs and the number of hospital days in the ICU, are parameters that increase direct costs $[13,14,15]$. For anesthesia, most frequently applied once, direct non-medical costs and the costs of the hospital, as well as the indirect costs are not significant due to reduced working ability.

\section{THE AIM}

According to the existing methodology:

1. To calculate the direct expense in anesthesia and reanimation;

2. To compare expenses to the price of anesthesia according to the unit prices of RFZO; 3 . To compare the duration of general anesthesia with costs in anesthesia departments;

\section{METHODS}

This paper is a part of retrospectively-prospectively designed academic (non-commercial) studies of the 4th phase authorized by the Ethics Committee of the Faculty of Medicine, University of Belgrade, No.470 / IV7.

Data were collected from the database of the Institute for Anesthesiology and Resuscitation, the Center for Social Medicine and Medical Statistics, Economic and Financial office, Center for medical supplies, the Center for Clinical pharmacology and Central Pharmacy. The obtained numerical data are processed by computer programs Microsoft Office Excel 2003 and SPSS for Windows. The data are statistically processed by Student $\mathrm{t}$ test and X2-test.

Personnel costs were calculated as the sum of the gross amount of salary per year, part-time employees, the anesthesiologists having 40 hours of overwork and anesthetists with secondary school qualifications and with two-year post-secondary school qualifications without overtime (work shifts). Personnel expenses are a fixed cost because they are calculated according to a Regulation on the coefficient for the calculation and payment of salaries of employees in public services[16]. The personnel costs do not include costs of administrative functions, teaching, Academic Positions and professional titles, continuous training and overtime nurses. Personal incomes of part-time employees were not taken into account.

Drugs used in anesthesia were as following: general and local anesthetics, analgesics, antidotes analgesics, and benzodiazepine, muscular relaxants, adrenergic agents, solutions (replacements for blood transfusion), solutions for intravenous administration for parenteral nutrition, electrolytic imbalance, electrolytes etc. Blood transfusion expenses and application of antibiotics were not included for departments of anesthesia and the ICU, but are counted as surgical intervention expenses[17]. Materials comprised endobronchial and the other tubes inserted to the airway, aspiration catheters, soda-lime, syringes, needles, gloves, and electrodes for ECG, patches, gauze, bandages, disinfectants, etc.

The necessary analyzes for anesthesia included: biochemical (blood count, glucose, urea, electrolytes and urine) hematologic (blood type, prothrombin time, partial thromboplastin time), radiologic (x-ray and lung) and electrocardiogram. The costs were valued as the single amount of RSD 2044 or EUR 26. Services such as cardiology, hematologic checkups etc. were not included. Medical equipment used in anesthesia included: apparatus for anesthesia, respirators, cardiorespiratory function monitors, defibrillators, bronchial aspirates, laryngoscopes, masks, intravenous pumps for intravenous administration of drugs, etc. 


\section{RESULTS}

The authors present direct costs of anesthetic services in 2005 and 2006 including all operated patients in the anesthesia departments of the surgical clinics in the Clinical Center of Serbia (CCS). Research groups included all patients of both sexes, children and adults (Table $1)$.

Table 1. Number of patients who received anesthesia in CCS in 2005 and 2006

Table 2. Total number of anesthesia services in 2005 and 2006 in CCS

Table 3. The average duration of hospital day and number of days in the IC and EC

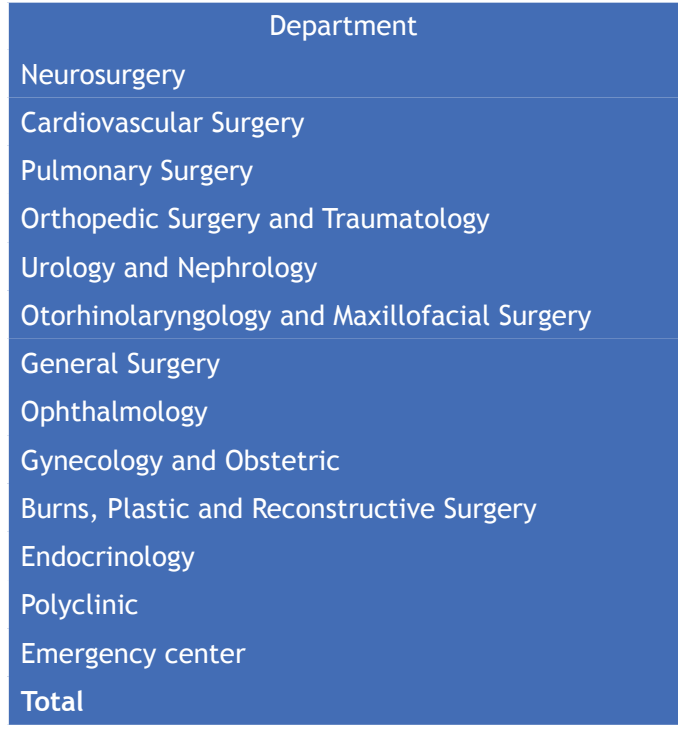

\begin{tabular}{|r|r|r|}
\hline 2005 & 2006 & \multicolumn{1}{|c|}{ Total } \\
\hline 2528 & 2513 & 5041 \\
\hline 3210 & 3571 & 6781 \\
\hline 607 & 602 & 1209 \\
\hline 1649 & 1913 & 3562 \\
\hline 1625 & 1867 & 3492 \\
\hline 2320 & 2385 & 4705 \\
\hline 3801 & 3940 & 7741 \\
\hline 3785 & 4183 & 7968 \\
\hline 3949 & 3891 & 7840 \\
\hline 1474 & 1435 & 2909 \\
\hline 799 & 761 & 1560 \\
\hline 0 & 0 & 0 \\
\hline 5275 & 5206 & 10481 \\
\hline 31022 & 32267 & 63289 \\
\hline
\end{tabular}
the anesthesiologist's responsibility are presented in Table 3.

The difference in the number of operated persons, operations and anesthesia services is interpreted by the number of surgical re-interventions and by needed anesthesia services. Operations done in UC are considered as emergency operations and anesthesia. Emer-

\begin{tabular}{|l|r|r|r|r|}
\hline \multicolumn{1}{|c|}{ Year } & General anesthesia & Local anesthesia & Anesthetic procedure & \multicolumn{2}{|c|}{ Total } \\
\hline 2005 & 32216 & 16323 & 20142 & 68681 \\
\hline 2006 & 33187 & 16394 & 20614 & 70195 \\
\hline Total & 65403 & 32717 & 40756 & 148876 \\
\hline
\end{tabular}

\begin{tabular}{|c|c|c|c|}
\hline Department & 2005 & 2006 & Total \\
\hline Neurosurgery & 3 & 2 & $<$ \\
\hline Cardiovascular Surgery & 2 & 2 & $=$ \\
\hline Pulmonary Surgery & 12 & 14 & $>$ \\
\hline Orthopedic Surgery and Traumatology & 3 & 3 & $=$ \\
\hline Urology and Nephrology & 2 & 3 & $>$ \\
\hline Otorhinolaryngology and Maxillofacial Surgery & 1 & 1 & $=$ \\
\hline General Surgery & 1 & 1 & $=$ \\
\hline Ophthalmology & 1 & 1 & $=$ \\
\hline Gynecology and Obstetric & 1 & 1 & $=$ \\
\hline Burns, Plastic and Reconstructive Surgery & 1 & 2 & $=$ \\
\hline Endocrinology & 1 & 1 & $=$ \\
\hline Polyclinic & 0 & 0 & 0 \\
\hline Emergence center & 8 & 6 & $<$ \\
\hline Arithmetic mean & 3 & 3 & $=$ \\
\hline
\end{tabular}




\begin{tabular}{|c|c|c|c|c|c|c|c|}
\hline 2006 Department & $\begin{array}{l}\text { Personal } \\
\text { cost } \%\end{array}$ & $\underset{\%}{\operatorname{Drug}}$ & $\begin{array}{l}\text { Material } \\
\%\end{array}$ & $\begin{array}{c}\text { Analysis } \\
\%\end{array}$ & $\begin{array}{l}\text { Apparatus } \\
\%\end{array}$ & $\begin{array}{l}\text { Direct } \\
\text { cost \% }\end{array}$ & $\begin{array}{l}\text { Unit } \\
\text { price \% }\end{array}$ \\
\hline General Surgery & 9,49 & 8,20 & 0,85 & 10,98 & 0,58 & 8,76 & 15,90 \\
\hline Endocrinology & 1,61 & 1,33 & 0,88 & 1,73 & 0 & 1,49 & 1,25 \\
\hline Gynecology and Obstetric & 10,33 & 9,15 & 6,00 & 17,56 & 9,50 & 11,63 & 14,25 \\
\hline Cardiovascular Surgery & 8,56 & 11,95 & 35,83 & 7,51 & 0 & 11,00 & 12,44 \\
\hline Neurosurgery & 9,11 & 10,09 & 5,37 & 5,03 & 0 & 7,78 & 23,61 \\
\hline Ophthalmology & 4,02 & 3,30 & 1,64 & 14,94 & 0 & 6,49 & 4,82 \\
\hline $\begin{array}{l}\text { Otorhinolaryngology and } \\
\text { Maxillofacial Surgery }\end{array}$ & 7,02 & 8,26 & 2,10 & 12,52 & 0 & 8,22 & 7,41 \\
\hline $\begin{array}{l}\text { Orthopedic Surgery and } \\
\text { Traumatology }\end{array}$ & 5,79 & 3,07 & 1,53 & 4,12 & 0 & 4,32 & 4,14 \\
\hline $\begin{array}{l}\text { Burns, Plastic and } \\
\text { Reconstructive Surgery }\end{array}$ & 3,48 & 2,26 & 0,82 & 2,80 & 0 & 2,76 & 1,35 \\
\hline Polyclinic & 2,67 & 0,35 & 0,28 & 3,14 & 0 & 2,06 & 0,75 \\
\hline Pulmonary Surgery & 1,84 & 3,46 & 2,19 & 2,36 & 0 & 2,32 & 1,54 \\
\hline Urology and Nephrology & 6,02 & 2,81 & 2,20 & 6,30 & 9,50 & 5,16 & 3,18 \\
\hline Emergence center & 30,06 & 35,78 & 40,32 & 11,01 & 80,42 & 28,00 & 9,36 \\
\hline Total & 100,00 & 100,00 & 100,00 & 100,00 & 100,00 & 100,00 & 100,00 \\
\hline
\end{tabular}

gency operations were $16 \%$ of the total, while $84 \%$ are elective or planned surgery and anesthesia. Polyclinic of CCS is a collection of the diagnostic potentials of CCS, specialized medical personnel and equipment of high technology including a number of departments of internal medicine and surgical branches, clinic, medical cabinets and daily hospitals. Services are fiscally freed from a debt very inaccurately in all departments of anesthesia and surgical clinics.

\section{Direct costs and "Unit prices" of NHIF}

The distribution of direct cost elements in the departments of anesthesia and 'Unit prices' is shown in Table 4.

Direct costs were the highest in the EC departments of anesthesia (28\%), gynecol-

\begin{tabular}{c|c|c|}
\hline Salary & Analysis & Drugs \\
\hline $42 \%$ & $26 \%$ & $22 \%$ \\
\hline
\end{tabular}

Obtained differences in direct costs (Tables 5 and 6) are the monetary policy of deflation in 2006 compared to 2005 by $9 \%$. Deflation is the opposite of the concept of inflation and marks a reduction of banknotes in circulation and thereby raising the purchasing value of money. Deflation policy is combating inflationary tendencies by disinflation reduced to

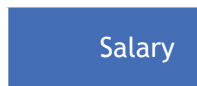

$40 \%$

\section{Drugs and materials}

ogy and obstetrics (11,63\%), cardiovascular diseases $(11 \%)$, general surgery $(8,76 \%)$ and in all others were lower.

Unit prices in the department of anesthesia were the highest in the field of Neurosurgery $(23,61 \%)$, General surgery $(15,9 \%)$, gynecology and obstetrics $(14,26 \%)$, cardiovascular disease $(12,44 \%)$, UC $(9,36 \%)$ and in the other departments were lover.

Cumulative direct costs are shown in Table 5 in percentages for 2006 .

Analysis of direct costs has shown that salaries require most resource spending, followed by biochemical analysis, hematologic analysis, drugs, and devices of minimal expenses.

Cumulative direct costs for 2005 and 2006 are shown in Table 6 in percentage.

\begin{tabular}{c|c|c} 
Materials & Apparatus & Direct costs \\
\hline $8 \%$ & $2 \%$ & $100 \%$
\end{tabular}

the extent considered as regular value [18], but that does not mean that the financial position of citizens and health care system is in better position.

\section{Personal expenses}

Number of medical staff has not changed in 2005 and 2006. Annual salary of anesthesiolo-
Table 4. Direct costs and Unit price per cent
Table 5. Direct costs summary per percent in departments 
Table 7. Personal salary of anesthesiologist and anesthetists per cent

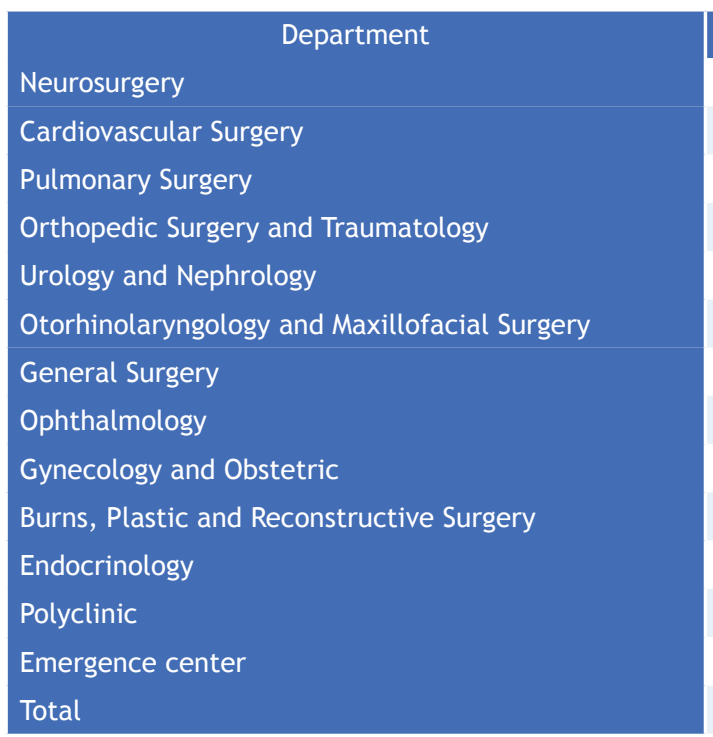

\begin{tabular}{|r|r|}
\hline 2005 & 2006 \\
\hline $9 \%$ & $9 \%$ \\
\hline $9 \%$ & $9 \%$ \\
\hline $2 \%$ & $2 \%$ \\
\hline $6 \%$ & $6 \%$ \\
\hline $6 \%$ & $6 \%$ \\
\hline $7 \%$ & $7 \%$ \\
\hline $9 \%$ & $9 \%$ \\
\hline $10 \%$ & $4 \%$ \\
\hline $3 \%$ & $10 \%$ \\
\hline $2 \%$ & $3 \%$ \\
\hline $3 \%$ & $2 \%$ \\
\hline $30 \%$ & $3 \%$ \\
\hline $100 \%$ & $30 \%$ \\
\hline
\end{tabular}

gist was EUR 8876 and of anesthetists EUR 4461 without past labor and overtime, tour of duty, standby and certain other fees paid on behalf of managers or teaching positions. Personnel costs have increased by $26 \%$ in 2006 compared to 2005 (Table 5, 6, 7), as the effect of deflation but the distribution of funds shown in percentage remained the same. Organization of the department of anesthesia and employees' distribution is influenced by the height and personnel costs. KCS is the largest reference institution in Serbia. EC has the largest number of Anesthesiologists and anesthetists because it works 365 days a year and 24 hours a day [19]. Personnel cost were $10 \%$ in the department of Gynecology and obstetrics clinic, followed by $9 \%$ in General, Neurosurgical and Cardiovascular clinic while on the other clinics were less.

1. Drugs, medical and non-medical supplies consumption

Direct costs of medicines and materials (Tab. 4) were almost the same in 2005 and 2006. EC expenses were less than $37 \%$ in 2006 than in 2005, in Cardiovascular Clinic were less than $18,3 \%$ and in Neurosurgical clinic were less than $8,8 \%$. The EC has spent $70 \%$ of its fund resources on drugs and $30 \%$ for medical and non- medical materials. EC expenses include overall sum of the consumption value in reanimation ambulance, 6 operation theater rooms and ICU. These expenses are distributed so that ICU had higher expenses than anesthesiological expenses in EC operation theater rooms.
Table 8. Average time of general anesthesia in the minute in department

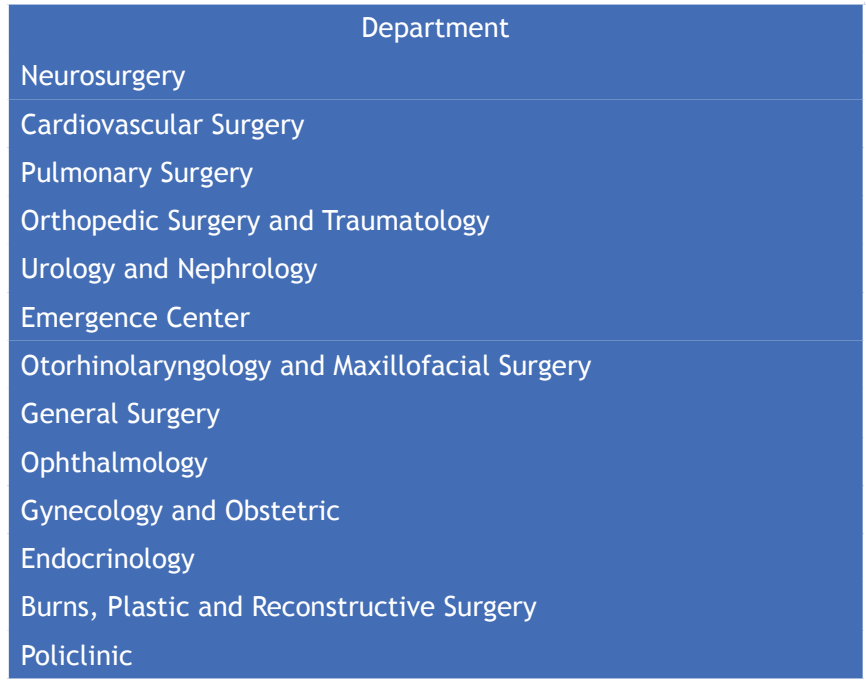

\begin{tabular}{|r|}
\hline Average time \\
\hline 378,29 \\
262,58 \\
210,00 \\
196,62 \\
157,43 \\
157,27 \\
138,94 \\
140,32 \\
130,81 \\
118,76 \\
92,09 \\
82,39 \\
51,93
\end{tabular}




\section{Other costs}

The cost analysis of anesthesia in 2006 were $26 \%$ and only $2 \%$ for devices. These costs are higher for $42 \%$ compared to 2005 due to the acquisition of new devices necessary for anesthesia (Table 4 and 5). All medical devices for anesthesia have certificates for use and must be serviced once a year, if necessary even earlier.

\section{General anesthesia average time}

Average time of general anesthesia in the operating theaters at surgical clinics is show in Table 7.

Traditionally, longest average time of general anesthesia was noticed in the fallowing departments: anesthesia departments, Neurosurgical, Cardiovascular and Pulmonary Clinic, noting that only a decade ago began rapid technological development in terms of the transition. Since then, more recent techniques and methods are applied in surgical procedures and materials (endoscopes, stents, etc.), significantly reducing the duration of general anesthesia.

We have proven the correlation of direct costs in anesthesia departments in its parent surgical clinics with average duration of general anesthesia (Figure 1). Direct costs indicate a linear correlation and statistically marked difference $\mathrm{p}=0,012, \mathrm{~F}=9,270$ compared to duration of anesthesia with coefficient of correlation $\mathrm{R}=0,694$. Direct costs are the highest in longest duration of anesthesia.

We have obtained linear correlation between direct costs as $\mathrm{R}=0,706$, 'unit prices' of anesthesia and anesthesia services as $\mathrm{F}=9,951$ and $\mathrm{p}=0,01$ (Figure 2), excluding the neurosurgical anesthesia.

We attempted, according to available data, to determine the direct costs of Anesthesiology and reanimation as soon as possible.

Realistic and transparent costs include medicines, medical supplies and devices because they have to be purchased from pharmaceutical and other medical companies. Therefore, they are exposed to constant checking and demanding for reduction of costs by those allocated for this purpose and/or using them in their line of work, administration and Government. Personnel and other costs are contract categories not sufficiently distinctive and transparent so we consider them as unrealistic costs.

Obtained results of the direct costs in anesthesia have shown that the personal in-

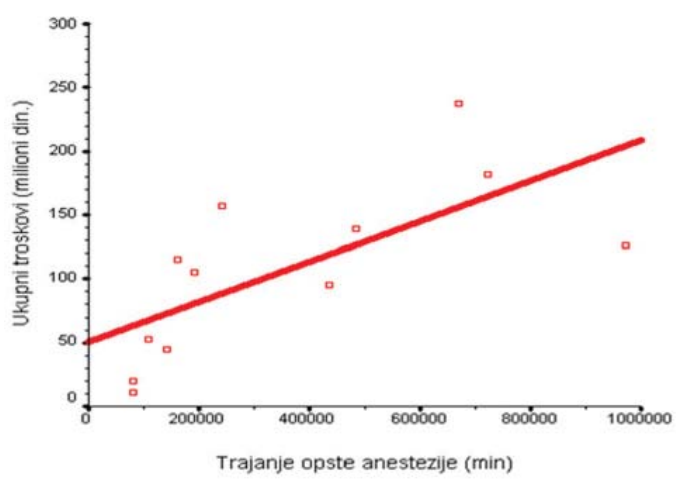

Figure 1. Linear correlation of direct costs and anesthesia duration

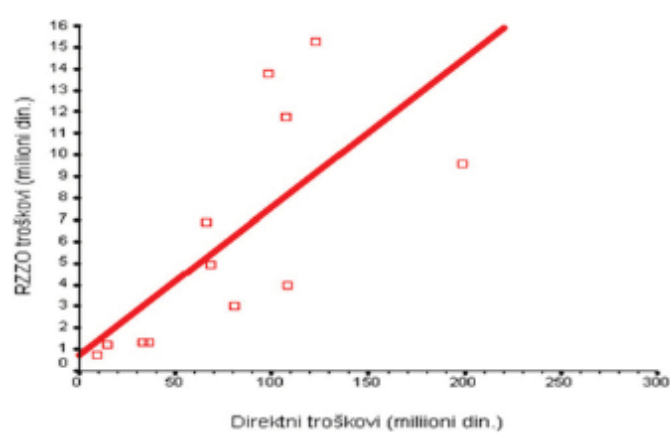

Figure 2. Direct costs correlation with 'unit prices' of anesthesiology services come amounted to $40 \%$; drugs and supplies to $31,80 \%$ and other costs to $28,20 \%$ of resources.

Personnel costs are higher due to labor of clinical doctors, experts and academics, past work, teaching positions and Continuous Education, which were not considered. It would not be properly compared with other countries due to the difference in our methodology of calculating personal income per performance, lists of patients, payment categories etc. Other studies show that the personal costs of anesthesiologists without nursing staff amount to $30 \%$ of costs[20]. According to our methodology of calculating, personnel costs were higher for larger stuff of anesthesiologists and anesthetists. Being for decades in the transition, it would not be appropriate to comment further reduction in personal incomes as a possibility to reduce the medical treatment costs.

Internationally accepted method of defined daily doses-DDD and Anatomic Therapeutic Classification- ATC of drugs registered in Serbia was used for researching anesthetic and other types of drugs consumption. DDD is mainly expressed in weight values of active substances 20. General and local anesthetics, muscular relaxants and i. v. solutions as well as some other drugs, do not have an established 
DDD and hence, it is recommend to provide alternative way of displaying the data in unit doses or single doses. Some of the characteristics of anesthetics and other drugs used in anesthesia are: non-repetitive applications, the simultaneous use of multiple group of strong effect drugs, various individual doses of the same drug (introduction and maintenance of anesthesia), exclusively intravenous or inhalation drug use, continuous intravenous and inhalation anesthetics application, muscular relaxants and other drugs using inhalation pumps or infusomats etc. The same drugs can be administered preoperatively, operatively and postoperatively. Dissolved drugs have limited preservation ability.

The studies have shown that the consumption of resources for anesthetic agents and other drugs used in anesthesia are the largest in EC, including 5,93\% of the resources of drugs in the CCS, and in accordance with other studies (5\%) [21]. Higher consumption of drugs was registered in the internal and surgical services [22].

The costs of inhalation anesthetics were $22,3 \%$, intravenous $16,6 \%$ and of muscular relaxants $14,9 \%$. Local anesthetics consumption included $1,2 \%$ of the funds for anesthetics and other drugs used in anesthesia. We do not intend to influence the selection of drugs that would affect the quality of anesthesia, but to provide prices of latest drugs as modern standard drugs for anesthesia. From the group of inhalation anesthetics, halothane, which has been in use for more than half a century gave way to newer, Sevorane, with a price that is 240 times greater than the cost of a halothane. In the group of intravenous anesthetics, etomidate was present 10 times less than the propofol and was three times cheaper than propofol.

We believe that the small resource savings are possible by reducing supply costs but not by the choice of anesthetics that would affect the quality of anesthesia. According to other studies, savings could theoretically be achieved by using local anesthesia whenever possible, then the techniques of anesthesia with low flow gases and using cheaper inhalation anesthetics $[23,24,25,26]$. The resulting costs of medical and non-medical supplies are less than 3\% not representing the real consumption due to imprecise distributions in the departments of surgical clinics. Another study states that the cost of supplies amounts to $2-10 \%$ of total costs [27].

The costs of laboratory analysis and devices are calculated only once for the anesthesia, but the analysis is repeated multiple times during anesthesia for urgent and highly specialized surgical operations and in the ICU, additionally increasing these costs.

The costs of supplies, maintaining and amortization of anesthesia devices, ventilator and monitoring are minimal. If purchase price would be included, the direct cost would be increased up to $10 \%$. The research results show that anesthesiologic equipment was scantily restored, unevenly and often unalotted as distributed in departments of anesthesia. Certificates of devices are regularly updated on the annual bases. Some modern technological solutions are applied in certain departments of anesthesia, such as monitoring patients' wakefulness in anesthesia by bispectral index. According to our opinions, the methodology of calculation of service costs, amortization of equipment and facilities is unconvincing although the study suggests that it is better to count services cost per square meter $\left({ }^{\mathrm{m} 2}\right)$ than per patient $[22,27]$.

Our results [13-15,28-30] do not indicate the possibility of further reducing costs and show a highly significant correlation of personnel costs, consumption of anesthetics and direct costs. The reason is disconnection between direct costs and 'unit prices' containing the type of anesthetic technique of specific duration, per hour and according to Price list of costs agreed with HIF. Considering direct costs, only the costs of anesthetics, drugs and supplies are realistic while all the other elements are determined by law and by contract with HIF. Other costs from the group of direct costs could be theoretically reduced by running analyzes required for anesthesia and for the planned surgical intervention in primary health care protection system.

Costs are influenced by the management of the anesthesia department and ICU as well as a way of financing health care protection system. Economic and pharmacoeconomic assessments put emphasis on the quality of the medical treatments and the potential profits for public and individual patients. Resources are distributed at government level. Resources for the community are determined by States, based on gross national income per capita and according to the health index of general population. General population health index 
is indicated by the general and specific rates of morbidity, absence rate and degree of disability. Despite these problems, the economic evaluations of drugs are becoming more popular.

\section{CONCLUSION}

- Researches have shown that the salaries consume the largest amount of resources (40\%), drugs, and supplies (32\%) and other costs less than $28 \%$.

- In the context of surgical intervention costs, perioperative anesthesia accounts for $10 \%$ ( $\mathrm{ABC}$ analysis).

- Anesthetics and other drugs used in anesthesia consume less than $5 \%$ of the agents for hospital drugs. Price of anesthetics and drugs has received considerable attention, especially cost of the newer, shorter duration inhaled anesthetics, intravenous analgesics and neuromuscular blocking agents. We believe that the small resource savings are possible by reducing supply costs but not by a choice of anesthetics that would affect the quality of anesthesia. Drugs and supplies are real costs and all other elements of direct costs are considered as agreed categories. The work and care of patients is hardest to cover in cash funds. The cost of analysis would be minimized if they were done in the primary health protection system.

- Clinical protocols of anesthetized patients should and can be better linked to the outpatient, departments, intensive care units and daily hospitals. Databases of drugs clinical route, Bookkeeping information systems and management of hospital information system should be specific, better managed and more accurate.

\section{REFERENCES}

1. Weiser TG, Regenbogen SE, Thompson KD, et al.An estimation of the global volume of surgery: a modelling strategy based on available data. Lancet 2008; 372:139-14.

2. Fasting S. Risk in anesthesia. Tidsskr Nor Laegefren.2010; 130(5):498-503.

3. Decision on common criteria and measures of setting the health service price-list. Official Gazette of the Republic of Serbia 3/91. on Serbian

4. Nomenklatura zdravstvenih usluga na sekundarnom I tercijalnom nivou zdravstvene zaštite. The nomenclature of health services at the secondary and tertiary levels of health care. Official Gazette of the Republic of Serbia 37/2014.on Serbian www. rfzo.rs/.../Nomenklatura\%20zdravstvenih\%20usluga\%20na\%20sekundarnom\%...

5. Pravilnik o cenama zdravstvenih usluga na sekundarnom i tercijalnom nivou zdravstvene zaštite. Regulations on prices of health services at the secondary and tertiary levels of health care.

http: / / www.rfzo.rs/download/pravilnici/ugovaranje/Pravilnik\%200\%20cenama\%20zdravstvenih\%20usluga\%20na\%20sekundarnom\%20i\%20tercijarnom\%20nivou\%20zz-14112014.pdf on Serbian

6. Abouleish AE, Prough DS, Whitten CW, Zomov $\mathrm{MH}$. The effects of surgical case duration and type of surgery on hourly clinical productivity of anesthesiologists. Anesth Analg 2003; 97:833-8.

7. Palmetto GBA.com-Providers/ Part B Carrier/ Ohio/Articles/Surgery/Anesthesia: Base \& Time Units. CMS Pub. 100-04, Chapter 12, Section 50:htpp:/cms.hhs.gov/manuals

8. Abouleish AE, Prough DS, Barker SJ, Whitten CW, Uchida T, Apfelbaum JL. Organization factors affect comparisons of the clinical productivity of academic anesthesiology departments. Anesth Anal 2003; 96:802-12

9. Novaković T. Priručnik za farmakoekonomske evaluacije. Handbook for pharmacoeconomic evaluations. Crown Agents-Projekt. Beograd 2006. On Serbian

10. Dexter F, Lubarsky DA, Gilbert BC, Thompson C. A method to compare costs of drugs and supplies among anesthesia providers: A simple statistical method to reduce variations in cost due to variations in casemix. 1998; 88(1): 350-6.

11. Sperry R: Principles of economic analysis. Anesthesiology 1997; 86:1197-205.

12. American Society of Anesthesiologists. 2002 Relative Value Guide: A Guide for Anesthesia Values. Park Ridge. Illinois. American Society of Anesthesiologists, 2002.

13. Majstorovic BM, Kastratovic DA, Vucovic DS, Milakovic BD, Milicic BR. Analiza operativnih troškova $\mathrm{u}$ anesteziji-ABCanaliza. Operating Cost Analysis of Anaesthesia: Activity Based Costing (ABC Analysis). Srp Arh Celok Lek. 2011; 139(7-8):501-508.on Serbian

14. Majstorović BM, Kastratović DA, Vućović DS, Milaković BD, Gojković-Bukarica LČ, Pekmezović TD. Farmakoekonomska procena troškova u anesteziologiji.Pharmaco-Economic Estimation of Cost in Anesthesiology. Pharmaca Serbica 2009;1(1.2):3640. On Serbian

15. Majstorović BM, Vučović DS, Milaković BD, Mikov MM, Mijajlovic MS, Markovic SZ, Kastratović DA. The Analysis of Direct Costs in Anesthesia. Journal of Pharmacy Research. 2011; 4(10):3520-24. (www. pronline.info) 
16. By-laws on coefficients for the calculation and payment of workers' salaries in the public services. Official Gazette of the Republic of Serbia 106/2006. on Serbian

17. Kastratović DA, Dukić VB, Majstorović BM, Komrska JJ, Gajić MM, Marković SZ. Antibiotic consumption monitoring at the Institute of Otorhinolaryngology and Maxillofacial Surgery--Clinical Center of Serbia in 2001-2003. Vojnosanit Pregl. 2005 Jul-Aug; 62(7-8):551-5.

18. https://velikirecnik.com > Reči od A do $D$ > Reči na slovo D. On Serbian.

19. Clinical Centre of Serbia, Emergency Centre web presentation. www.kcs.ac.rs/index.php/home -15. januar 2017.

20. Farrar S, Yi D, Sutton M, Chalkley M, Sussex J, Scott $A$. Has payment by results affected the way that English hospitals provide care? Difference-indifferences analysis. BMJ. 2009; 339:b3047.

21. Lekovi u prometu: priručnik o lekovima i njihovoj primeni, urednici: Jakovljević V, Sabo A, Tomić Z. Ortomediks, Novi Sad 2009. On Serbian

22. TA for Capacity Building for Tertiary Care Services Republic of Serbia. A project funded by the European Union. Belgrade: Ministry of Health of the Republic of Serbia, European Investment Bank / Sofreco; 2006.

23. Odin I, Feiss P. Low flow and economics of inhalational anesthesia. Best Pract Res Clin Anaesthesiol. 2005; 19(3):399-413.

24. Meyer T. Managing inhaled anesthesia: challenges from a health-system pharmacist's perspective. Am J Health Syst Pharm. 2010 Apr 15;67(8 Suppl 4):S4-8.

25. World Federation of Societies of Anaesthesiologists. 2008 International Standards for a Safe Practice of Anesthesia. Available on: http://anaesthesiologists.org/en/safety/2008-nternationalstandards-for-a-safe-practice-of-anaesthesia.html. Accessed February 28, 2011.

26. Nordin P, Zetterström H, Carlsson P, Nilsson E. Cost-effectiveness analysis of local, regional and general anaesthesia for inguinal hernia repair using data from a randomized clinical trial. $\mathrm{Br} J$ Surg. 2007; 94(4):500-5.

27. Hikiji W, Kai T, Shiraishi K. An investigation on the profits from surgery and anaesthesia in Kyushu University Hospital. Masui.2008; 57(1):87-91.

28. Majstorović BM, Kastratović DA, Milaković BD, Marković SZ, Mijajlović MS, Vucović DS.Troškovi anestetika I drugih lekova u anesteziji. Costs of anesthetics and other drugs in anesthesia. Med Pregl. 2012; 65(1-2):30-4. On Serbian.

29.Majstorović BM, Simić S, Milaković BD, Vucović DS, Aleksić VV. Deskriptivna analiza rada I trendovi u anesteziji 2005. I 2006. Godine:kvantitativni । kvalitativni aspekti efekata I vrednovanja anestezije.[Descriptive analysis of work and trends in anaesthesiology from 2005 to 2006: quantitative and qualitative aspects of effects and evaluation of anaesthesia.Srp Arh Celok Lek. 2010 Sep-Oct; 138(9-10):624-31. On Serbian.

30. Majstorović BM, Milaković BD, Kastratović DA, Milićić BR, Vucićević VR. Smanjenje direktnih troškova u anesteziji nije put ka racionalizaciji troškova $u$ anesteziji. Reductions in anesthesia direct costs is not the right way for rationalization of anesthesia costs. Med Pregl. 2012; 65(9-10):421-7. On Serbian. 


\title{
Realni i nerealni direktni troškovi u farmakoekonomskim studijama u anesteziologijia
}

\author{
Branislava M. Majstorović ${ }^{1}$, Branko D. Milaković1,2 \\ ${ }^{1}$ Institut za anesteziologiju i reanimatologiju Kliničkog centra Srbije, Beograd, Srbija \\ ${ }^{2}$ Medicinski fakultet Univerziteta u Beogradu, Beograd, Srbija
}

\section{KRATAK SADRŽAJ}

Uvod: Mnogobrojnost anestezioloških usluga i veština pojedinačno troše malo sredstava, ali zbirno, troškovi su značajni. Ekonomske i farmakoekonomske studije se uvek rade u cilju racionalizacije sredstava.

Cilj: 1. Izračunati direktne troškove u anesteziologiji i reanimatologiji; 2 . uporediti dužinu opšte anestezije sa troškovima; 3 . uporediti troškove sa cenom anestezija prema "jediničnim cenama" Republickog fonda zdravstvenog osiguranja (RFZO).

Metod: Ovaj rad je deo retrospektivno-prospektivne akademske studije IV faze koja se sprovodi u Klinickom centru Srbije. Sa dozvolom Etičkog komiteta, odredili smo za 2005 i 2006 godinu, direktne troškove 148,876 anestezioloških usluga u 11 anestezioloških odelenja Kliničkog centra Srbije, ustanovi tercijalnog tipa zdravstvene zaštite. Istraživana grupa je obuhvatile sve bolesnike, oba pola, decu i odrasle. Uporedili smo direktne troškove po minuti opšte anestezija sa prosečnom dužinom anestezija po odeljenjima anestezije u hirurškim klinikama. Direktne troškove smo uporedili sa istim, ,jediničnim“ cenama RFZO. Za analizu komponenata troškova koristili smo linerani i regresioni statistički model /SPSS 15/.

Rezultati: Najveći deo sredstava se troši na plate zaposlenih (40\%), zatim na lekove i materijal $(31,80 \%)$ i ostale troškove gde se ubrajaju analize i aparati $(28,20 \%)$. Direktni troškovi pokazuju linearnu korelaciju i statistički značajnu razliku $p=0.012, F=9,270 \mathrm{u}$ odnosu na dužinu anestezije gde je koeficijenat korelacije $R=0,694$. Direktni troškovi su najveći kod najdužih anestezija. Dobili smo lineanu korelaciju $R=0,706$ direktnih troškova, izuzimajući neurohiruršku anesteziju, sa „jediničnim cenama“ anestezija i anestezioloških usluga gde je $F=9,951$ i $p=0,01$.

Zaključak: Anestezije i anesteziološke usluge pokazuju statistički značajnu i finansijski važnu korelaciju direktnih troškova sa dužinom anestezija u okviru različitih hirurških specijalnosti. U direktnim troškovima jedino su realni troškovi anestetika, lekova i materijala, a svi ostali elementi se određuju prema zakonskim aktima i ugovorom sa RZZO. Ostali troškovi, iz grupe direktnih troškova bi se teoretski mogli smanjiti izvođenjem analiza neophodnih za anesteziju, za planiranu hiruršku intervenciju u primarnoj zdravstvenoj zaštiti. Baze podataka povezane sa hirurškim, bolji kompjuterski programi koji mogu da prate više parametara tokom bolničkog lečenja, mogli bi preciznije odrediti vrednost anestezioloških usluga.

Ključne reči: opšta anestezija, direktni troškovi, indirektni troškovi, ukupni troškovi 